\title{
PENGARUH MODEL PEMBELAJARAN KOOPERATIF TIPE THINK PAIR SHARE BERBANTUAN MEDIA INTERAKTIF TERHADAP HASIL BELAJAR MENULIS BERITA SISWA KELAS VIII SMP PGRI 2 BULELENG TAHUN PELAJARAN 2017/2018
}

\author{
Komang Surya Adnyana, Ni Made Rai Wisudariani, I Nengah Martha \\ Jurusan Pendidikan Bahasa dan Sastra Indonesia \\ Fakultas Bahasa dan Seni \\ Universitas Pendidikan Ganesha \\ Singaraja, Indonesia \\ e-mail: suryaadnyana510@yahoo.com ${ }^{1}$, rai.wisudariani85@gmail.com², \\ nengahmartha@yahoo.com²
}

\begin{abstract}
ABSTRAK
Penelitian ini bertujuan untuk mengetahui (1) hasil belajar menulis berita siswa kelas VIII SMP PGRI 2 Buleleng tahun pelajaran 2017/2018, (2) pengaruh penerapan model pembelajaran kooperatif tipe think pair share berbantuan media interaktif terhadap hasil belajar menulis berita siswa kelas VIII SMP PGRI 2 Buleleng tahun pelajaran 2017/2018. Jenis penelitian yang digunakan adalah penelitian quasi eksperimen. Data dikumpulkan dengan menggunakan tes dalam bentuk penugasan berupa menulis teks berita. Data hasil belajar menulis berita siswa dianalisis menggunakan statistik deskriptif dan inferensial. Hasil penelitian menunjukkan (1) hasil belajar menulis berita siswa kelas VIII SMP PGRI 2 Buleleng adalah 80 terletak pada kategori sangat tinggi dan 72 dengan kategori tinggi, (2) Hasil uji hipotesis menunjukkan bahwa terdapat perbedaan yang signifikan. Hal ini terlihat pada hasil analisis uji-t dengant $t_{\text {hitung }}$ lebih besar dari $t_{\text {tabel }}$ yaitu 5,44 $>1,67$ dengan derajat kebebasan 49. Hasil belajar menulis berita yang signifikan inilah menunjukkan bahwa ada pengaruh penggunaan model pembelajaran kooperatif tipe think pair share berbantuan media interaktif terhadap hasil belajar menulis berita siswa kelas VIII SMP PGRI 2 Buleleng tahun ajaran 2017/2018.
\end{abstract}

Kata Kunci : model dan media pembelajaran, hasil belajar menulis

\begin{abstract}
This research aimed at investigating (1) students' writing achievement of eighth grade of SMP PGRI 2 Buleleng in academic year 2017/2018, (2) The effect of cooperative learning model Think Pair Share with interactive media toward the students' writing achievement of eighth grade of SMP PGRI 2 Buleleng in academic year 2017/2018. This was a quasi experimental study. The data were collected by using test in a form of news writing assignment. The data were analyzed by using descriptive and inferential statistic. The result of this research shows (1) students' news writing achievements of eighth grade of SMP PGRI 2 Buleleng are 80 lies in very high category and 72 in high category, (2) The hypothesis test shows a significant difference. The result is shown in the T-test with T-count is higher than T-table which is $5.44>1.67$ with 49 degrees of freedom. The significant result of this study proves that the cooperative learning model Think Pair Share with interactive media has a positive significant effect toward students' learning achievement of news writing of the eighth grade in SMP PGRI 2 Buleleng academic year 2017/2018.
\end{abstract}


Keywords: model and learning media, students' writing achievement

\section{PENDAHULUAN}

Pendidikan memegang peran penting untuk mencerdaskan dan mencetak sumber daya manusia (SDM) yang cerdas dan unggul. Untuk meningkatkan sumber daya manusia secara maksimal, diperlukan sistem pendidikan yang baik dan selalu diperbaharui sesuai dengan perkembangan ilmu pengetahuan dan teknologi (IPTEK). Mutu pendidikan yang berkualitas dan professional sangat diperlukan agar mampu menciptakan sumber daya manusia yang unggul dan berkualitas. Pembaharuan sistem pendidikan mencakup semua komponen pendidikan seperti pembaharuan kurikulum, proses belajar mengajar, peningkatan kualitas guru, pengadaan buku pelajaran dan sarana belajar lainnya, penyempurnaan sistem penilaian, dan juga menajemen pendidikan.

Dalam upaya meningkatkan kualitas pembelajaran di sekolah menengah pertama (SMP), pemerintah telah melakukan berbagai upaya. Upaya yang telah dilakukan di antaranya melakukan penyediaan sumber belajar yang relevan, pelatihan guru, dan penyediaan sarana dan prasarana yang memadai. Sementara itu, terkait dengan pembelajaran yang telah dilakukan di sekolah, keberhasilan dalam kegiatan pembelajaran di sekolah tidak lepas dari berbagai faktor, guru, model pembelajaran, media pembelajaran, sarana dan prasarana pembelajaran, situasi dan kondisi kelas, serta faktor siswa sebagai peserta didik, misalnya. Hal itulah yang menjadi kunci keberhasilan dalam menjalankan pembelajaran di sekolah.

Sebagai seorang pendidik, guru memiliki tugas yang berat agar bisa menciptakan manusia yang memiliki wawasan luas. Mengingat saat ini peserta didik cenderung lebih senang bermain daripada belajar. Seorang guru dalam proses pembelajaran haruslah memiliki kecakapan, keterampilan, dan pengetahuan yang luas agar dapat melaksanakan proses pembelajaran sesuai dengan apa yang diharapkan. Seorang guru harus mampu memotivasi siswa dan juga memiliki pemikiran yang kritis terhadap situasi dan kondisi yang dihadapi saat pembelajaran berlangsung. Artinya, guru harus siap menghadapi berbagai macam karakter yang berbeda-beda dari peserta didik. Selan itu, dalam proses pembelajaran guru harus mampu menggunakan model dan media pembelajaran yang kreatif dan inovatif. Ketidaktepatan guru dalam memilih model dan media pembelajaran tentu akan berpengaruh terhadap hasil belajar siswa.

Hasil belajar merupakan kemampuan keterampilan, sikap dan keterampilan yang diperoleh siswa setelah menerima perlakuan yang diberikan oleh guru, sehingga dapat mengkonstruksikan pengetahuan itu dalam kehidupan seharihari, Sudjana (2005:22). Selan itu, Sumartono (dalam Rahman, 2012:158) mengemukakan bahwa hasil belajar adalah suatu nilai yang menunjukkan hasil yang tertinggi dalam belajar yang dicapai menurut kemampuan anak dalam mengerjakan sesuatu pada saat tertentu. Rendahnya hasil belajar disebabkan karena guru kurang kreatif dan inovatif dalam memilih model dan media pembelajaran yang digunakan dalam proses pembelajaran di kelas.

Berbagai kelemahan tersebut lebih diakibatkan oleh kekurangsiapan guru dalam memberikan inovasi dalam pembelajaran dan pemberian model serta media pembelajaran yang kurang tepat. Kurangnya kreativitas dan inovasi guru ini dalam mengolah pembelajaran, maka peserta didik cenderung pasif dalam mengikuti pembelajaran di kelas. Beberapa siswa menyatakan bahwa siswa kurang bergairah dalam mengikuti proses pembelajaran karena cara mengajar guru sangat membosankan sehingga siswa sering mengantuk dan bercanda dengan teman pada saat proses belajar mengajar 
berlangsung. Dengan demikian, minat belajar siswa yang rendah baik dalam bertanya, menjawab maupun berpendapat akan berpengaruh terhadap penguasaan serta pemahaman materi yang diajarkan. Dalam hal ini, siswa tidak bisa memberikan respon terhadap pertanyaan yang diberikan oleh guru. Dalam hal ini, kemampuan berkomunikasi siswa masih rendah.

Dalam kemampuan berkomunikasi baik secara lisan maupun tulis dalam pembelajaran bahasa dan sastra Indonesia meliputi kegiatan mendengarkan, berbicara, membaca, dan menulis. Setiap keterampilan berhubungan dengan tiga keterampilan lainnya. Dalam memperoleh keterampilan berbahasa, biasanya melalui suatu urutan yang teratur. Mula-mula sejak kecil belajar menyimak bahasa kemudian dilanjutkan dengan berbicara, sesudah itu belajar membaca dan menulis. Keterampilan menyimak dan berbicara didapatkan oleh seseorang melalui peniruan yang bersifat alamiah dan langsung dalam proses komunikasi. Keterampilan menulis didapatkan seseorang melalui latihan yang rutin sehingga memperoleh hasil yang baik.

Menulis merupakan kegiatan yang ekspresif dan produktif. Ekspresif dalam arti bahwa dengan menulis dapat mengekspresikan dan mengungkapkan ide, gagasan, dan pengalaman untuk dikomunikasikan kepada orang lain. Keterampilan seseorang untuk mengungkapkan ide, gagasan, pikiran, dan pengetahuan sebagai suatu keterampilan menulis yang produktif. Menulis dipengaruhi oleh keterampilan produktif lainnya, seperti aspek berbicara maupun keterampilan reseptif yaitu aspek membaca dan menyimak serta pemahaman kosakata, diksi, keefektifan kalimat, penggunaan ejaan, dan tanda baca. Kompetensi menulis tidak akan datang secara otomatis, melainkan harus melalui latihan dan praktik yang banyak dan teratur, Tarigan (dalam Amalia, 2013:3).

Menulis tidak ada kaitannya dengan bakat. Menulis hanya memerlukan latihan yang optimal. Maksud dari latihan yang optimal tersebut yaitu latihan yang terus menerus tanpa putus asa dan ketika menemui suatu masalah tidak langsung menyerah melainkan mencari solusi untuk mengatasinya. Dalam praktik pembelajaran menulis terjadi komunikasi dua arah antara guru sebagai penutur dan siswa sebagai mitra tutur. Berhasil atau tidaknya suatu pembelajaran dipengaruhi oleh beberapa faktor di antaranya faktor siswa, guru, dan suasana yang kondusif. Suasana kondusif akan mendorong minat belajar siswa secara optimal guna mengembangkan kemampuan yang dimiliki. Di dalam kurikulum KTSP tahun 2006 terdapat kompetensi dasar pembelajaran menulis yaitu menulis teks berita secara singkat, padat, dan jelas untuk siswa SMP kelas VIII. Hal ini merupakan salah satu bentuk perhatian pemerintah akan pentingnya kompetensi atau kemampuan siswa dalam menulis teks berita. Berita selalu menjadi bahan pembicaraan orang setiap hari. Dengan adanya berita akan menambah pengetahuan dan wawasan seseorang mengenai kejadian atau peristiwa tertentu. Siswa SMP kelas VIII diharapkan dapat menulis teks berita dengan baik. Pada taraf ini siswa SMP kelas VIII sudah mampu mengamati dan menangkap informasi yang terdapat dalam berita.

Berdasarkan hasil observasi dan wawancara dengan guru mata pelajaran Bahasa Indonesia kelas VIII SMP PGRI 2 Buleleng, saat ini kondisi keterampilan menulis teks berita siswa masih rendah. Rendahnya keterampilan menulis teks berita siswa terlihat dari siswa belum mampu menentukan unsur berita. Siswa juga belum mampu mengembangkan unsur-unsur berita menjadi kalimat-kalimat yang sesuai dengan maksud unsur beritanya, dan siswa belum mampu menyusun teks berita dengan benar.

Setelah dilakukan wawancara, rendahnya keterampilan menulis teks berita disebabkan oleh dua faktor yaitu faktor dari guru dan siswa. Guru kurang memberi pelatihan pada siswa bagaimana menulis yang benar. Praktik menulis jarang dilaksanakan dalam pembelajaran menulis dan siswa hanya mengerjakan tugas atau 
latihan di LKS. Kegagalan lain juga disebabkan oleh pemakaian teknik dan model yang kurang tepat. Guru masih menggunakan model tradisional yaitu ceramah. Guru memberikan penjelasan teoretis tentang bagaiman menulis teks berita yang baik, bagaimana bahasa berita, apa saja syarat-syarat sebuah berita, dan sebagainya. Siswa kemudian diharuskan menulis teks berita dengan tema yang telah ditentukan oleh guru. Hasil pekerjaan siswa dikumpulkan dan dikoreksi sendiri oleh guru tanpa adanya pembahasan mengenai materi yang sudah dipelajari.

Model pembelajaran ini mengakibatkan siswa kurang mampu menerapkan unsur-unsur teks berita. Dari faktor siswa, siswa tidak memperhatikan pada waktu proses pembelajaran menulis teks berita. Siswa kurang tertarik dengan pembelajaran menulis dan terkesan pasif. Melihat kenyataan tersebut, guru perlu mengadakan berbagai upaya dan mencoba berbagai alternatif, baik strategi maupun model pembelajaran yang bervariasi agar siswa tidak bosan dan tidak jenuh dalam mengikuti pembelajaran menulis teks berita. Guru perlu menerapkan model pembelajaran yang dapat menarik minat dan motivasi siswa.

Untuk mengatasi permasalahan tersebut, guru harus melaksanakan proses pembelajaran yang kreatif dan inovatif. Inovasi yang dimaksud adalah sebuah cara guru yang dapat membuat perubahan sehingga guru dapat memfasilitasi siswa dalam belajar. Perubahan yang dimaksud yaitu perubahan peran guru dalam pembelajaran, perubahan orientasi pembelajaran, hingga perubahan ruang lingkup pembelajaran. Dengan mengubah peran guru yang mulanya berorientasi pada siswa menjadi berorientasi pada siswa. Dengan sistem pembelajaran seperti ini, maka siswa akan lebih aktif dalam mengikuti proses pembelajaran di sekolah.

Salah satu model pembelajaran inovatif yang dapat memfasilitasi siswa dalam belajar adalah model pembelajaran think pair share. Shoimin (2014:209) menyatakan bahwa think pair share memiliki prosedur yang secara eksplisit memberi siswa waktu untuk berpikir, menjawab, dan saling membantu satu sama lain. Selain itu, pembelajaran kooperatif tipe think pair share merupakan pembelajaran kelompok dengan memberi kesempatan kepada siswa untuk berpikir mandiri dan saling membantu dengan teman yang lain. Think pair share sebagai model pembelajarana yang efektif untuk membuat variasi suasana pola diskusi kelas. Dengan menerapkan model pembelajaran ini, siswa akan tertarik mengikuti pembelajaran karena siswa merasa ada sesuatu yang baru dalam kegiatan pembelajaran yang menantang sehingga dapat membantu memecahkan masalah-masalah yang ditemukan.

Selain dengan menggunakan model pembelajaran dalam proses pembelajaran di kelas, guru juga perlu menggunakan media pembelajaran yang menarik sehingga siswa lebih aktif dalam mengikuti pembelaran yang diberikan. Artinya, media pembelajaran yang digunakan dapat menarik perhatian siswa dan dapat menyampaikan pesan pembelajaran berupa materi pelajaran yang sesuai dengan rencana pembelajaran atau target pembelajaran yang ingin dicapai. Gagne (dalam Asyhar, 2012:7) menyatakan media pembelajaran adalah berbagai komponen pada lingkungan belajar yang membantu pembelajar untuk belajar. Media pembelajaran yang dapat digunakan adalah media interaktif.

Media interaktif dipilih dikarenakan media ini dapat menarik minat belajar siswa. Hal tersebut dikarenakan media pembelajaran interaktif merupakan suatu sistem penyampaian pengajaran yang menyajikan materi video rekaman dengan pengendalian komputer kepada penonton (siswa) yang tidak hanya mendengar dan melihat video dan suara, tetapi juga memberikan respon yang aktif, dan respon itu yang menentukan kecepatan dan sekuensi penyajian. Dengan demikian, siswa akan serius dan aktif mengikuti proses pembelajaran di kelas.

Penggunaan model pembelajaran kooperatif tipe think pair share berbantuan media interaktif relevan diterapkan pada 
situasi kelas yang cenderung pasif untuk merangsang serta mendorong minat siswa untuk belajar. Penerapan model dan media pembelajaran ini adalah salah satu upaya untuk mendorong dan meningkatkan semangat belajar siswa sehingga hasil belajar tinggi. Berdasarkan permasalahan di atas, maka dilakukan penelitian yang berjudul "Pengaruh Model Pembelajaran Kooperatif Tipe Think Pair Share Berbantuan Media Interaktif Terhadap Hasil Belajar Menulis Berita Siswa Kelas VIII SMP PGRI 2 Buleleng Tahun Pelajaran 2017/2018". Penelitian ini dilakukan guna mengetahui ada atau tidaknya pengaruh penggunaan model pembelajaran kooperatif tipe think pair share berbantuan media interaktif terhadap hasil belajar menulis berita siswa.

\section{METODE}

Penelitian ini dilakukan dengan
metode eksperimen dengan alasan
penelitian ini berusaha mencari pengaruh
suatu variabel terhadap variabel lainnya.
Penelitian eksperimen merupakan
penelitian yang dimaksudkan untuk
mengetahui ada tidaknya akibat dari
"sesuatu" yang dikenakan pada subjek
selidik. Gay (dalam Emzir, 2012:64)
menyatakan penelitian eksperimental
merupakan satu-satunya metode penelitian
yang dapat menguji secara benar hipotesis
menyangkut hubungan kausal (sebab-
akibat). Jenis penelitian yang digunakan
dalam penelitian ini adalah quasi
eksperimen.

Populasi dalam penelitian ini adalah siswa kelas VIII SMP PGRI 2 Buleleng. Pemilihan sampel dengan "Teknik Cluster Random Sampling". Teknik Random Sampling adalah teknik pengambilan anggota sampel dari populasi dilakukan secara acak tanpa memperhatikan strata yang ada dalam populasi itu. Sehingga diperoleh kelas VIII-A sebagai kelas eksperimen dan kelas VIII-B sebagai kelas kontrol. Dalam penelitian eksperimen, ada tiga tahapan yang harus dilakukan, yaitu persiapan, pelaksanaan, dan akhir ekperimen.

Pada penelitian ini, pengumpulan data dilakukan dengan metode tes. Metode tes yang digunakan adalah metode tes dalam bentuk penugasan menulis berita. Penugasan menulis berita digunakan untuk mengetahui hasil belajar menulis berita siswa.

Untuk menentukan tinggi rendahnya kualitas variabel-variabel penelitian, skor rata-rata (mean) tiap-tiap variabel dikonversikan dengan menggunakan kriteria rata-rata ideal $(\mathrm{Xi})$ dan standar deviasi ideal (SDi).

Setelah diberikannya post test berupa menulis berita kepada kelompok eksperimen mapun kelompok kontrol, maka akan diperoleh hasil belajar menulis berita siswa. Hasil belajar menulis berita siswa akan dianalisis. Analisis data dalam penelitian ini adalah analisis statistik deskriptif dan analisis statistik inferensial. Analisis deskriptif yaitu dimaksudkan untuk mendeskripsi data dengan memberi pemaknaan untuk menguji hipotesis penelitian. Mengingat analisis ini menggunakan statistik parametrik terutama untuk menguji hipotesis eksperimen maka diperlukan persyaratan analisis: a) data harus berdistribusi normal, b) data harus homogen.

Analisis deskriptif digunakan untuk mengetahui tinggi rendahnya kualitas dari dua variabel yaitu metode pembelajaran dan hasil belajar menulis berita siswa yang dihitung melalui nilai rata-rata (mean), modus, median, standar deviasi, dan varians. Setelah didapatkan data secara deskriptif, maka dilanjutkan dengan uji-t.

Sebelum dilakukan analisis t-test, data harus dalam keadaan berdistribusi normal dan varians dalam kelompok homogen.Terkait dengan hal tersebut, sebelum menggunakan analisis t-test data harus diuji normalitas dan homogenitasnya. Apabila data berdistribusi normal, maka pengujian hipotesis dilakukan dengan statistika parametrik, tetapi apabila data berdistribusi tidak normal, maka pengujian hipotesis dilakukan dengan menggunakan statistika nonparametrik. Hal ini dilakukan 
untuk mengetahui taraf signifikan kedua kelompok. Rumus yang digunakan untuk mencari uji-t adalah sebagai berikut.

(separated varian)

$$
\mathrm{t}=\frac{\overline{\mathrm{x}}_{1}-\overline{\mathrm{x}}_{2}}{\sqrt{\frac{\mathrm{s}_{1}^{2}}{\mathrm{n}_{1}}+\frac{\mathrm{s}_{2}^{2}}{\mathrm{n}_{\mathrm{n}}}}}
$$

(Poolled Varian)

$t=\frac{\bar{x}_{1}-\bar{x}_{2}}{\sqrt{\frac{\left(n_{1}-1\right) s_{1}^{2}+\left(n_{2}-1\right) s_{2}^{2}}{n_{1}+n_{2}-2}\left(\frac{1}{n_{1}}+\frac{1}{n_{2}}\right)}}$

(Sugiyono, 2009:179)

\section{HASIL DAN PEMBAHASAN}

Hasil penelitian berisi hasil belajar siswa yang meliputi: (1) proses belajar menulis berita, (2) deskripsi hasil penelitian, (3) uji prasyarat, (4) uji hipotesis, dan (5) pembahasan hasil penelitian. Proses belajar menulis berita berisi mengenai pelaksanaan pembelajaran pada kelas eksperimen dan kelas kontrol. Deskripsi hasil belajar siswa dilakukan untuk mengetahui nilai mean, median, modus, standar deviasi, dan varians kedua kelompok.

Rata-rata skor (mean) ini akan dikonversi berdasarkan penilaian acuan patokan berikut.

Tabel 1. Pedoman Konversi Nilai Hasil Belajar Absolut Skala Lima

\begin{tabular}{|c|l|c|}
\hline No & \multicolumn{1}{|c|}{ Rentang Skor } & $\begin{array}{c}\text { Klasifika } \\
\text { si }\end{array}$ \\
\hline 1 & $\begin{array}{l}\mathrm{Xi}+1,5 \mathrm{SDi} \leq \mathrm{X} \leq \mathrm{Xi}+ \\
3,0 \mathrm{SDi}\end{array}$ & $\begin{array}{c}\text { Sangat } \\
\text { Tinggi }\end{array}$ \\
\hline 2 & $\begin{array}{l}\mathrm{Xi}+0,5 \mathrm{SDi} \leq \mathrm{X}<\mathrm{Xi}+ \\
1,5 \mathrm{SDi}\end{array}$ & Tinggi \\
\hline 3 & $\begin{array}{l}\mathrm{Xi}-0,5 \mathrm{SDi} \leq \mathrm{X}<\mathrm{Xi}+ \\
0,5 \mathrm{SDi}\end{array}$ & Cukup \\
\hline 4 & $\mathrm{Xi}-1,5$ SDi $\leq \mathrm{X}<\mathrm{Xi}-$ & Rendah \\
\hline
\end{tabular}

\begin{tabular}{|l|l|l|}
\hline & $0,5 \mathrm{SDi}$ & \\
\hline 5 & $\mathrm{Xi}-3,0 \mathrm{SDi} \leq \mathrm{X}<\mathrm{Xi}-$ & $\begin{array}{l}\text { Sangat } \\
\text { rendah }\end{array}$ \\
\hline
\end{tabular}

(Dimodifikasi dari Koyan, 2012:25)

Berdasarkan pedoman konversi di atas, maka diperoleh skala penilaian hasil belajar menulis berita siswa yang belajar dengan menggunakan model pembelajaran kooperatif tipe think pair share berbantuan media interaktif maupun siswa yang belajar dengan pembelajaran konvensional. Skala penilaian hasil belajar menulis berita dapat dilihat pada tabel 2 berikut ini.

Tabel 2. Skala Penilaian Hasil Belajar Menulis Berita

\begin{tabular}{|c|c|}
\hline Rentang Skor & Klasifikasi \\
\hline $75-100$ & Sangat Tinggi \\
\hline $58,4-74$ & Tinggi \\
\hline $41,8-58,3$ & Cukup \\
\hline $25,01-41,7$ & Rendah \\
\hline $0,2-25$ & Sangat rendah \\
\hline
\end{tabular}

Pedoman konversi dan skala penilaian dilkukan untuk mengetahui hasil belajar menulis berita kelompok eksperimen maupun kelompok kontrol.

Hasil analisis skor hasil belajar menulis berita kelompok eksperimen terhadap 26 siswa di kelas VIII-A dengan menggunakan model pembelajaran kooperatif tipe think pair share berbantuan media interaktif menunjukkan bahwa skor tertinggi yang diperoleh siswa adalah 86 dan skor terendah adalah 70 .

Tabel 3.Distribusi frekuensi kelompok eksperimen dapat dilihat pada tabel berikut.

\begin{tabular}{|c|c|c|c|c|}
\hline $\begin{array}{c}\text { Kelas } \\
\text { Interval }\end{array}$ & $\begin{array}{c}\text { Batas } \\
\text { Bawah } \\
\text { Kelas }\end{array}$ & $\begin{array}{c}\text { Titik } \\
\text { Tengah(X) }\end{array}$ & F & Fk \\
\hline $70-72$ & 69,5 & 71 & 2 & 2 \\
\hline
\end{tabular}




\begin{tabular}{|c|c|c|c|c|}
\hline $73-75$ & 72,5 & 74 & 4 & 6 \\
\hline $76-78$ & 75,5 & 77 & 2 & 8 \\
\hline $79-81$ & 78,5 & 80 & 9 & 17 \\
\hline $82-84$ & 81,5 & 83 & 1 & 18 \\
\hline $85-87$ & 84,5 & 86 & 8 & 26 \\
\hline \multicolumn{3}{|c|}{ Total } & 26 & \\
\hline
\end{tabular}

Berdasarkan tabel distribusi di atas, maka diperoleh (mean) rerata kelompok eksperimen sebesar 80 , nilai median 80 nilai modus sebesar 85,73 , varian sebesar 22,2, dan standar deviasi sebesar 4,71.

Berdasarkan kriteria hasil belajar menulis berita yang telah dijelaskan sebelumnya dan sesuai dengan hasil analisis data, bahwa rata-rata (mean) hasil belajar menulis berita kelompok siswa yang belajar dengan model pembelajaran kooperatif tipe think pair share berbantuan media interaktif adalah 80. Oleh karena itu, hasil belajar menulis berita siswa kelas VIIIA SMP PGRI 2 Buleleng terletak pada kategori sangat tinggi.

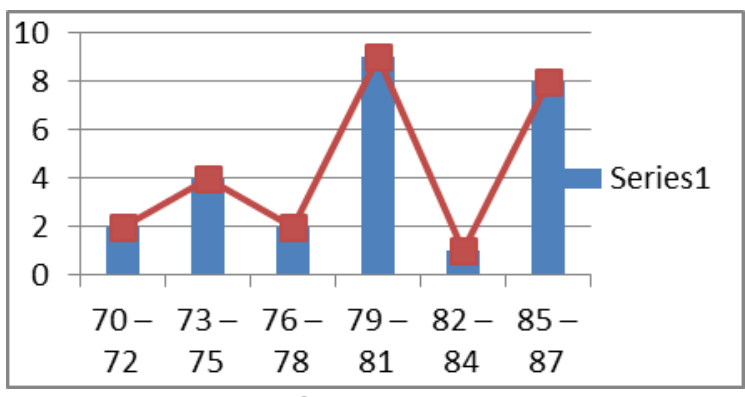

Gambar 1.

Kurve Histogram dan Poligon Hasil Belajar Menulis Berita Kelompok Eksperimen

Hasil analisis kelompok kontrol terhadap 25 siswa yang belajar dengan menggunakan model pembelajaran konvensional menunjukkan bahwa skor tertinggi yang diperoleh siswa adalah 82 dan skor terendah adalah 60. Distribusi frekuensi kelompok kontrol dapat dilihat pada tebel 4 berikut.

Tabel 4. Distribusi Frekuensi Kelompok Kontrol

\begin{tabular}{|c|c|c|c|c|}
\hline $\begin{array}{c}\text { Kelas } \\
\text { Interval }\end{array}$ & $\begin{array}{c}\text { Batas } \\
\text { Bawah } \\
\text { Kelas }\end{array}$ & $\begin{array}{c}\text { Titik } \\
\text { Tengah(X) }\end{array}$ & F & Fk \\
\hline
\end{tabular}

\begin{tabular}{|c|c|c|c|c|}
\hline $60-63$ & 59,5 & 61,5 & 1 & 1 \\
\hline $64-67$ & 63,5 & 65,5 & 4 & 5 \\
\hline $68-71$ & 67,5 & 69,5 & 10 & 15 \\
\hline $72-75$ & 71,5 & 73,5 & 4 & 19 \\
\hline $76-79$ & 75,5 & 77,5 & 1 & 20 \\
\hline $80-83$ & 79,5 & 81,5 & 5 & 25 \\
\hline \multicolumn{5}{|c|}{ Total } \\
\hline
\end{tabular}

Berdasarkan tabel distribusi kelompok kontrol di atas, maka diperoleh nilai mean sebesar 72 , nilai median 70,5 , nilai modus 81,1 , nilai varian 33,5 dan standar deviasi sebesar 5,78.

Berdasarkan kriteria hasil belajar menulis berita yang telah dijelaskan sebelumnya dan sesuai dengan hasil analisis data, bahwa rata-rata (mean) hasil belajar menulis berita kelompok siswa yang belajar dengan pembelajaran konvensional. Adalah 72. Oleh karena itu, hasil belajar kelompok kontrol terletak pada kategori tinggi.

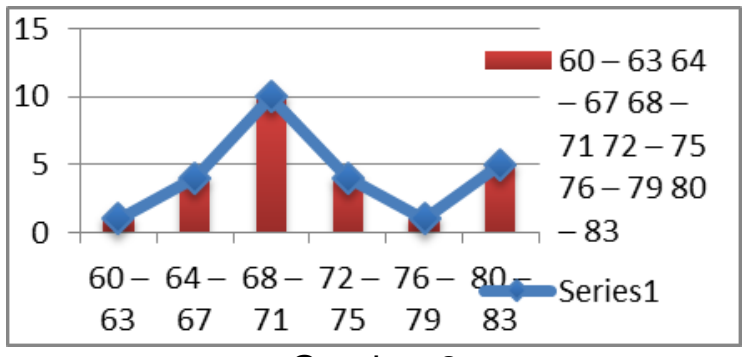
Gambar 2

Kurve Histogram dan Poligon Hasil Belajar Menulis Berita Kelompok Kontrol

Setelah dilakukannya analisis statistik deskriptif pada hasil belajar menulis berita kelompok eksperimen dan kelompok kontrol, maka dilakukan uji prasyarat.Sebelum dilakukan analisis uji-t, maka data harus dalam keadaan normal dan homogen. Hal ini dilakukan untuk mengetahui uji signifikansi kedua kelompok. Berikut ini akan dipaparkan mengenai uji normalitas dan homogenitas pada kelompok eksperimen dan kelompok kontrol.

Uji normalitas data dilakukan pada keseluruhan unit analisis yaitu kelompok yang belajar dengan model pembelajaran kooperatif tipe think pair share berbantuan media interaktif. Uji normalitas ini dilakukan 


\begin{tabular}{|c|c|c|c|c|c|}
\hline Sampel & Mean & SD & Varian & $F_{\text {hittung }}$ & $\mathrm{F}_{\text {tabel }}$ \\
\hline $\begin{array}{c}\text { Kelomp } \\
\text { ok } \\
\text { Eksperi } \\
\text { men }\end{array}$ & 80 & $\begin{array}{l}4,7 \\
1\end{array}$ & 22,2 & \multirow[t]{2}{*}{$\begin{array}{l}1,50 \\
9\end{array}$} & \multirow[t]{2}{*}{3,19} \\
\hline $\begin{array}{c}\text { Kelopo } \\
\text { k } \\
\text { Kontol }\end{array}$ & 72 & $\begin{array}{l}5,7 \\
8\end{array}$ & 33,5 & & \\
\hline \multicolumn{4}{|c|}{ Simpulan } & \multicolumn{2}{|c|}{ Homogen } \\
\hline
\end{tabular}

dengan menggunakan Chi Kuadrat $\left(X^{2}\right)$ pada taraf $5 \%$.

Setelah dilakukannya perhitungan terhadap hasil belajar kelompok eksperimen, maka diperoleh $\mathrm{dk}=6-2-1=$ 3 pada tabel $X^{2}$ untuk taraf signifikan $5 \%=$ 7,815. Dengan demikian, harga $X_{\text {hitung }}^{2}=3,656<$ harga $X_{\text {tabel }}^{2}=7,815$ sehingga $H_{0}$ diterima. Jadi, diterimanya $H_{0}$ berarti data hasil post test menulis berita siswa yang dibelajarkan dengan model pembelajaran kooperatif tipe think pair share berbantuan media interaktif berdistribusi normal.

Uji normalitas data juga dilakukan pada kelompok kontrol. Setelah dilakukannya perhitungan, maka diperoleh $\mathrm{dk}=6-2-1=3$ pada tabel $X^{2}$ untuk taraf signifikan $5 \%=7,815$. Dengan demikian, harga $X_{\text {hitung }}^{2}=2.2165<$ harga $X_{\text {tabel }}^{2}=7,815$ sehingga $H_{0}$ diterima. Jadi, diterimanya $H_{0}$ berarti data hasil post test menulis berita siswa yang dibelajarkan dengan pembelajaran konvensional berdistribusi normal.

Setelah data dalam keadaan normal, maka kedua data dicari homogenitas kedua kelompok. Uji homogenitas varians dilakukan terhadap varians pasangan antara kelompok eksperimen dan kelompok kontrol.Rumus yang digunakan adalah uji-F dengan kriteria homogen jika $\mathrm{F}_{\text {hitung }}<\mathrm{F}_{\text {tabel. }}$. Hasil uji homogenitas dapat dilihat pada tabel berikut.
Tabel 5.Hasil Uji Homogenitas Varians dengan Uji $\mathrm{F}$

Berdasarkan tabel di atas, hasil uji homogenitas varians untuk kelas yang belajar dengan menggunakan model pembelajaran kooperatif tipe think pair share berbantuan media interaktif dan pembelajaran konvensional diketahui $\mathrm{F}_{\text {hitung }}=1,509$ pada taraf signifikan $5 \%$, dan harga $F_{\text {tabel }}=3,19(1,509<3,19)$. Dengan demikian, $\mathrm{H}_{1}$ ditolak dan $\mathrm{H}_{0}$ diterima. Jadi, varians post test homogen.

Berdasarkan uji prasyarat analisis data, diperoleh bahwa data hasil post test kelompok eksperimen dan kontrol adalah normal dan homogen. Setelah diperoleh hasil dari uji prasyarat analisis data, dilanjutkan dengan pengujian hipotesis penelitian $\left(\mathrm{H}_{1}\right)$ dan hipotesis $\left(\mathrm{H}_{0}\right)$. Pengujian hipotesis ini dilakukan dengan menggunakan uji-t sampel independent (tidak berkolerasi) dengan rumus Poolled Varian dengan kriteria pengujian jika $t_{\text {hitung }}>t_{\text {tabel }}$ maka $H_{0}$ ditolak dan $H_{1}$ diterima. Sementara jika $t_{\text {hitung }}<t_{\text {tabel }}$ maka $H_{0}$ diterima dan $H_{1}$ ditolak.Ringkasan hasil analisis uji-t dapat dilihat pada tabel berikut.

Tabel 6. Hasil Uji-T Post Test Hasil Belajar Menulis Berita

\begin{tabular}{|c|c|c|c|c|c|}
\hline Kelas & Varian & $\mathbf{N}$ & Db & $\boldsymbol{t}_{\text {hitung }}$ & $\boldsymbol{t}_{\text {tabel }}$ \\
\hline $\begin{array}{c}\text { Eksperi } \\
\text { men }\end{array}$ & 22,2 & 26 & & 5,44 & 1,67 \\
\hline Kontrol & 33,5 & 25 & 49 & & \\
\hline \multicolumn{3}{|c|}{ Simpulan } & & \multicolumn{3}{c|}{ Signifikan } \\
\hline
\end{tabular}

uji-t, diperoleh $t_{\text {hitung }}$ sebesar 5,44.

Sementara, $t_{\text {tabel }}$ dengan taraf signifikansi $5 \%$ dan db $=n_{1}+n_{2}-2$ adalah 1,67. Ini berarti, $t_{\text {hitung }}$ lebih besar dari $t_{\text {tabel }}$ $\left(t_{\text {hitung }}>t_{\text {tabel }}\right)$ sehingga $H_{0}$ ditolak dan $H_{1}$ diterima. Dengan demikian, perbedaan hasil belajar menulis berita kedua kelompok signifikan. Hasil perhitungan uji-t yang 
signifikan, menunjukkan bahwa ada pengaruh penggunaan model pembelajaran kooperatif tipe think pair share berbantuan media interaktif terhadap proses dan hasil belajar menulis berita.

\section{PEMBAHASAN}

Proses belajar mengajar yang berlangsung di SMP PGRI 2 Buleleng khususnya pada siswa kelas VIII menggunakan 2 model pembelajaran, yaitu model pembelajaran kooperatif tipe think pair share pada kelas eksperimen dan model pembelajaran konvensional (ceramah) pada kelas kontrol. Proses belajar menulis berita pada kelompok eksperimen akan diberikan sebuah perlakuan yaitu dengan menggunakan model pembelajaran kooperatif tipe think pair share berbantuan media interaktif. Proses pembelajaran yang dilakukan sesuai dengan langkah-langkah pembelajaran koperatif tipe think pair share. Penggunaan model pembelajaran ini guna menarik minat belajar siswa dalam mengikuti pembelajaran.

Proses belajar menulis berita pada kelompok kontrol dilaksanakan sesuai dengan sintak pembelajaran konvensional. Proses pembelajaran dilakukan dengan pemberian informasi oleh guru, tanya jawab, pemberian tugas, oleh guru, dan pelaksanaan tugas oleh siswa sampai pada akhirnya guru merasa bahwa apa yang telah diajarkan dimengerti oleh siswa. Pelaksanaan model pembelajaran konvensional ini membuat siswa merasa bosan dalam mengikuti pembelajaran. Hal ini dikarenakan guru yang lebih aktif dalam proses pembelajaran sedangkan siswa hanya sebagai pendengar.

Proses pembelajaran yang berlangsung baik pada kelas eksperimen maupun kelas kontrol dilaksanakan sesuai dengan model pembelajaran yang bersangkutan. Efektifnya penggunaan model pembelajaran dalam proses pembelajaran akan berpengaruh terhadap hasil belajar siswa. Hasil belajar yang diperoleh siswa dalam suatu periode tertentu ditentukan oleh faktor keaktifan siswa dalam mengikuti proses pembelajaran. Selain itu, model pembelajaran yang digunakan guru juga berpengaruh terhadap hasil belajar siswa. Pembahasan hasil penelitian dan pengujian hipotesis menyangkut tentang hasil belajar menulis berita siswa baik pada kelompok siswa yang belajar dengan model pembelajaran kooperatif tipe think pair share berbantuan media interaktif maupun pada kelompok siswa yang belajar dengan pembelajaran konvensional.

Dalam penelitian ini, hasil belajar menulis berita siswa yang belajar dengan model pembelajaran kooperatif tipe think pair share berbantuan media interaktif maupun siswa yang belajar dengan menggunakan pembelajaran konvensional pada siswa kelas VIII di SMP PGRI 2 Buleleng menunjukkan adanya perbedaan hasil belajar setelah diberikannya post test pada pertemuan terakhir. Hal ini dapat dilihat dari hasil analisis data yang telah dilakukan dengan menggunakan analisis deskriptif dan inferensial (uji-t).

Secara deskriptif, hasil belajar menulis berita kelompok yang mengikuti pembelajaran dengan model pembelajaran kooperatif tipe think pair share berbantuan media interaktif memiliki hasil belajar yang lebih tinggi dibandingkan dengan kelompok siswa yang mengikuti pembelajaran dengan pembelajaran konvensional. Hal ini didasarkan pada rata-rata skor hasil belajar siswa. Rata-rata skor hasil belajar siswa yang mengikuti pembelajaran dengan model pembelajaran kooperatif tipe think pair share berbantuan media interaktif adalah 80 dan rata-rata skor hasil belajar yang mengikuti pembelajaran dengan pembelajaran konvensional adalah 72 .

Berdasarkan analisis inferensial yang menggunakan $u j i-t$, diketahui $\mathrm{t}_{\text {hitung }}=$ 5,44 dan $t_{\text {tabel }}(\mathrm{db}=49$ dan taraf signifikansi $5 \%)=1,67$. Hasil perhitungan tersebut menunjukkan bahwa $t_{\text {hitung }}$ lebih besar dari $t_{\text {tabel }}\left(t_{\text {hitung }}>t_{\text {tabel }}\right)$. Ini berarti, terdapat perbedaan yang signifikan antara siswa yang belajar dengan menggunakan model pembelajaran kooperatif tipe think pair share berbantuan media interaktif dengan siswa yang belajar 
menggunakan pembelajaran konvensional (ceramah).

Dari hasil analisis tersebut, tentu saja terdapat berbagai hal yang menyebabkan terjadinya perbedaan hasil belajar menulis berita secara signifikan antara siswa yang belajar dengan model pembelajaran kooperatif tipe think pair share berbantuan media interaktif dan siswa yang belajar dengan pembelajaran konvensional. Hal tersebut terjadi karena model pembelajaran ini menawarkan pengalaman belajar baru bagi siswa, karena melalui model pembelajaran ini siswa akan diberikan kesempatan untuk belajar berpikir, kemudian berpasangan untuk mencari solusi, dan kemudian membagikan hasil pemikiran mereka kepada teman-tema sekelasnya. Model pembelajaran think pair share adalah strategi diskusi kooperatif yang dikembangkan oleh Frank Lyman dan koleganya dari Universitas Mayland pada tahun 1982. Shoimin (2014:208) menjelaskan bahwa "think pair share adalah salah satu model pembelajaran kooperatif yang memberi siswa waktu untuk berfikir dan merespon serta saling bantu satu lain antar anggota kelompok".

Tahap pembelajaran dalam model ini diawali dengan kegiatan berfikir (think) yaitu guru mengajukan pertanyaan atau isu yang berhubungan dengan pembelajaran, kemudian siswa diarahkan untuk mencari jawabannya. Tahap kedua dilanjutkan denga berpasangan (pair) pada tahap ini siswa diarahkan untuk berdiskusi denga pasangannya dan tahap ketiga dilanjutkan dengan berbagi (share) pada tahap ini siswa diarahkan untuk menyampaikan hasil diskusi di depan kelas.

Selain dengan menggunakan model pembelajaran yang efektif, pendidik perlu menggunakan media pembelajaran yang tepat. Media interaktif sebagai salah satu media pembelajaran yang dapat menarik perhatian siswa untuk belajar. Pemberian materi pelajaran akan disajikan dalam bentuk media intektif. Media interaktif merupakan suatu sistem penyampaian pengajaran yang menyajikan materi video rekaman dengan pengendalian komputer kepada penonton (siswa) yang tidak hanya mendengar dan melihat video dan suara, tetapi juga memberikan respon yang aktif, dan respon itu yang menentukan kecepatan dan sekuensi penyajian.

Jadi, penerapan model pembelajaran kooperatif tipe think pair share berbantuan media interaktif sebagai salah satu model arternatif yang dapat meningkatkan kemauan siswa dalam mengikuti proses pembelajaran. Model pembelajaran kooperatif tipe think pair share berbantuan media interaktif merupakan model dan media pembelajaran yang relevan diterapkan pada situasi kelas yang cenderung pasif untuk merangsang serta mendorong minat siswa untuk belajar. Penggunaan model dan media pembelajaran ini dalam proses pembelajaran, selain dapat melatih untuk berbicara, pembelajaran ini akan menciptakan suasana yang menyenangkan dan membuat siswa aktif. Jadi, semakin tepatnya model pembelajaran kooperatif tipe think pair share berbantuan media interaktif digunakan dalam proses pembelajaran sehingga berpengaruh terhadap hasil belajar siswa. Dengan demikian, hasil belajar siswa menjadi optimal atau tinggi.

Berbeda dengan pembelajaran konvensional, guru yang lebih aktif dan siswa hanya mendengarkan penjelasan guru. Dalam pelaksanaan pembelajaran konvensional ditandai dengan ceramah serta pembagian tugas dan latihan. Pada penerapannya, pembelajaran konvensional pada perencanaan sudah sangat maksimal tetapi penerapan atau proses pembelajaran ini masih berpusat pada guru. Pada saat proses pembelajaran berlangsung siswa lebih banyak mendengarkan dan mencata hal-hal penting yang disampaikan oleh guru, sehingga dalam proses pembelajaran guru lebih mendominasi sedangkan siswa cenderung pasif (Astawa dalam Prasetiyani, 2014:13). Oleh sebab itu, pembelajaran konvensional kurang efektif dan siswa merasa bosan dalam proses pembelajaran di kelas, sehingga hasil pembelajaran yang dicapai kurang maksimal. 
Berdasarkan uraian di atas, terlihat bahwa model pembelajaran kooperatif tipe think pair share berbantuan media interaktif lebih unggul dibandingkan dengan pembelajaran konvensional. Ini berarti, terdapat perbedaan yang signifikan hasil belajar menulis berita kedua kelompok. Hasil belajar siswa yang signifikan inilah menunjukkan bahwa ada pengaruh penggunaan model pembelajaran kooperatif tipe think pair share berbantuan media interaktif terhadap hasil belajar menulis berita.

Hasil penelitian ini sejalan dengan hasil penelitian yang dilakukan oleh Kadek Ria Ari Astini dan Ni Made Astini Asih. Penelitian yang dilakukan Kadek Ria Ari Astini berjudul Penerapan Teknik ThinkPair-Share untuk Meningkatkan Kemampuan Menulis Teks Diskusi Siswa Kelas VIII.2 SMP Negeri 2 Singaraja. Hasil penelitian yang dilakukan oleh Kadek Ria Ari Astini menunjukkan bahwa (1) kemampuan menulis teks diskusi siswa kelas VIII.2 SMP Negeri 2 Singaraja meningkat, hal ini tampak pada siklus I sebesar 75,78 dan pada siklus II sebesar 79,08 ; (2) langkah-langkah yang tepat dalam pembelajaran menulis teks diskusi adalah berpikir mengenai topik yang telah diberikan (think), mendiskusikannya bersama pasangannya (pair), dan sharing tentang hasil kerjanya; (3) penerapan teknik think-Pair-Share untuk meningkatkan kemampuan menulis teks diskusi mendapatkan respons positif pada siklus I dengan skor 27,68 dan respons sangat positif terjadi pada siklus II dengan skor 29,67. Simpulan dari penelitian yang dilakukan oleh Kadek Ria Ari Astini menunjukkan penggunaan teknik think-pairshare dapat meningkatkan kemampuan menulis teks diskusi.

Hal tersebut juga sejalan dengan penelitian yang dilakukan oleh $\mathrm{Ni}$ Made Astini Asih yang berjudul Penerapan Model Pembelajaran Think Pair Share untuk Meningkatkan Aktivitas Memecahkan Masalah dan Hasil Belajar dalam Mata Pelajaran PKN Siswa Kelas VIIIA MTS. AlKhairiyah Tegallinggah Tahun Ajaran 2012/201. Hasil penelitian yang dilakukan oleh Ni Made Astini menunjukan bahwa, (1) ada tiga langkah utama dalam model pembelajaran TPS yaitu tahap think (berpikir), tahap pair (berpasangan) dan tahap share (berbagi). (2) Aktivitas memecahkan masalah pada siklus I nilai rata-ratanya sebesar 56,28 yang berada pada kategori cukup baik sedangkan pada siklus II nilai rata-ratanya sebesar 79,71 yang berada pada kategori baik dan mengalami peningkatan sebesar $23,43 \%$. (3) Hasil belajar siswa siklus I nilai rataratanya sebesar 69,11 dengan kategori cukup dan ketuntasan belajar siswa $46,43 \%$ sedangkan pada siklus II nilai rata-ratanya sebesar 82,32 dengan ketuntasan belajarnya sebesar $89,28 \%$ dan mengalami peningkatan sebesar $13,22 \%$. (4) Adapun kendala dalam penerapan model pembelajaran TPS adalah keterbatasan sumber belajar, minat belajar siswa dan tingkat intelegensi siswa. Solusinya yaitu peneliti menyiapkan materi tambahan dan melakukan pendekatan kepada siswa yang kurang aktif serta melakukan pengawasan yang lebih seksama.

Kedua hasil penelitian tersebut menunjukkan bahwa penerapan model pembelajaran think pair share dapat meningkatkan hasil belajar dan memberikan pengaruh yang signifikan terhadap hasil belajar. Jadi, pembelajaran yang menggunakan model pembelajaran kooperatif tipe think pair share berbantuan media interaktif berpengaruh terhadap proses dan hasil belajar menulis berita siswa kelas VIII SMP PGRI 2 Buleleng Tahun Pelajaran 2017/2018.

\section{SIMPULAN}

Berdasarkan hasil penelitian dan pembahasan sebelumnya, maka dapat disimpulkan yaitu (1) pembelajaran yang berlangsung di kelas VIII SMP PGRI 2 Buleleng, menggunakan 2 model pembelajaran. Pada kelas kontrol, guru melakukan proses pembelajaran tanpa memberikan perlakuan atau guru akan menggunakan pembelajaran konvensional atau cermah. Akan tetapi, pada kelas eksperimen guru memberikan perlakuan 
yaitu dengan menggunakan model pembelajaran kooperatif tipe think pair share berbantuan media interaktif. Dalam proses pembelajaran, penggunaan model kooperatif think pair share berbantuan media interaktif lebih efektif digunakanan dalam proses pembelajaran, (2) hasil belajar menulis berita siswa yang belajar dengan menggunakan model pembelajaran kooperatif tipe think pair share berbantuan media interaktif lebih tinggi dibandingkan dengan siswa yang belajar menggunakan pembelajaran konvenional. Hal tersebut dapat dilihat dari rata-rata hasil belajar kedua kelompok. Hasil belajar menulis berita siswa yang belajar dengan model pembelajaran kooperatif tipe think pair share berbantuan media interaktif adalah 80 terletak pada kategori sangat tinggi. Sedangkan, hasil belajar siswa yang belajar dengan menggunakan pembelajaran konvensional adalah 72 dengan kategori tinggi, (3) hasil uji hipotesis menunjukkan bahwa terdapat perbedaan yang signifikan antara kelompok siswa yang belajar dengan menggunakan model pembelajaran kooperatif tipe think pair share berbantuan media interaktif dengan kelompok siswa yang belajar dengan menggunakan pembelajaran konvensional. Hal ini terlihat pada hasil analisis uji-t dengant $t_{\text {hitung }}$ lebih besar dari $t_{\text {tabel }}$ yaitu $5,44>1,67$ dengan derajat kebebasan 49. Hasil belajar menulis berita yang signifikan inilah menunjukkan bahwa ada pengaruh penggunaan model pembelajaran kooperatif tipe think pair share berbantuan media interaktif terhadap hasil belajar menulis berita siswa kelas VIII SMP PGRI 2 Buleleng tahun ajaran 2017/2018.

\section{UCAPAN TERIMAKASIH}

Peneliti menyadari bahwa penelitiannya tidak akan terwujud tanpa bantuan dari pihak lain. Oleh sebab itu, melalui kesempatan ini, disampaikan ucapan terimakasih kepada $\mathrm{Ni}$ Made Rai Wisudariani, S.Pd. M.Pd., selaku pembimbing I dan Prof. Dr. I Nengah Martha, M.Pd., selaku pembimbing II yang telah memberikan arahan, bimbingan, motivasi, serta masukan yang sangat berarti dalam penelitian ini.

\section{DAFTAR RUJUKAN}

Asih, Ni Made Astini. 2013. Penerapan Model Pembelajaran Think Pair Share untuk Meningkatkan Aktivitas Memecahkan Masalah dan Hasil Belajar dalam Mata Pelajaran PKN Siswa Kelas VIIIA MTS. Al-Khairiyah Tegallinggah Tahun Ajaran 2012/2013. Jurusan Pendidikan Pancasila dan Kewarganegaraan, FIS Undiksha.

Astini, Kadek Ria Ari. 2016. Penerapan Teknik Think-Pair-Share untuk Meningkatkan Kemampuan Menulis Teks Diskusi Siswa Kelas VIII.2 SMP Negeri 2 Singaraja. Jurusan Pendidikan Bahasa dan Sastra Indonesia, FBS Undiksha.

Asyhar, Rayandra. 2012. Kreatif Mengembangkan Media Pembelajaran. Jakarta: Referensi Jakarta.

Amalia, Zuhruf. 2013. Peningkatan Keterampilan Menulis Teks Berita Melalui Media Foto Peristiwa Pada Peserta Didik Kelas VIIIA SMP N 5 Pekalongan Tahun Ajaran 2012/2013. Fakultas Bahasa dan Seni Universitas Negeri Semarang.

Emzir.2012. Metodologi Penelitian Pendidikan Kuantitatif \& Kualitatif. Jakarta: Rajawali Pers.

Koyan, I Wayan. 2012. Statistik Pendidikan. Singaraja. Universitas Pendidikan Ganesha Press.

Prasetiyani. 2014. "Pengaruh Pembelajaran Kooperatif Tife Gl (Group Investigation) Berbantuan Media Gambar Terhadap Hasil Belajar PKN Kelas III Semester Ganjil di Gugus IV Kecamatan Banjar Tahun Pelajaran 2013/2014.

Shoimin, Aris. 2014. 68 Model Pembelajaran Inovatif dalam Kurikulum 2013. Yogyakarta:Ar-Ruzz Media. 
Sudjana, Nana. 2005. Penilaian Hasil Proses Belajar Mengajar. Bandung: PT. Remaja Rosdakarya.

Sugiyono. 2009. Metode Penelitian Pendidikan Kuantitatif, Kualitatif dan $R \& D$. Bandung: Alfabeta. 